
れをフィードバックするのである。そして今，ここの問 題に没頭する点で, 実存的な修練である。

（2）次に池田はT グループと治療集団の異同について のべた。治療集団は病人が集まつた同質の集団で，治療 者にたより, 治療者が一切の責任をもつて行ら点で, $\mathrm{T}$ グループの異質的な正常人の集団で, トレーナーに頼ら ずに，自律的に行う集団とは区別される。ただし、テー マ, 座長のない free floating discussion をする集団と いら点では，2つの集団は共通である。なお，Tグルー プは super-ego を破壊するが，治療集団は defence mechanism を破壊する。Tグループの目的は tolerance だが，非能率だ。

（3）次に井原は銀行の管理者研修，女子訓練，得意先 係研修などで， Т グループを採用するが，効果は少い。 現場では人間関係の円満でない者は陶汰し，もつと役に 立つ訓練をする。目標を定めないで強行軍をやらせる と, Tグループよりずつと早く欲求不満に陥り，その tolerance が着われる。また知らない家を訪れて，奉仕 をさせたり，京都一灯円に派遣して修業させる。これは 金を扱うので, とくに污職をしない人格訓練をするため だ,と発表した。

（4）堀江はキリスト教と Tグループの関係についのべ た。

人間関係といらのは「我と汝」の関係である。処がわ れわれは「我と物」の関係になりやすい。旧約聖書のな かで，神は弟アベルを殺した兄カインに「弟アベルはど こにいるか」と問われた。カインは「知りません。私は 弟の番人でしょらか」と答えた。カインは弟を物として 殺し，弟との人格的関係をたり切つた。その時，カイン は人ではなかつた。キリストは隣人に対して，隣人とな ることを求めている。集団生活の経験を通して人は人と なり，神にあつての人間関係は人をさらに霊的に成長さ せるから，神の前に正しい集団のあり方が教えられなけ ればならない。その意味で, キリスト教会生活の Tグル ープは産業界の Tグループとは違うなど，のべられた。

（5）以上の発表につづいてフローアとの間に次のよう な討論があうた。

1. 池田は病人と正常人という点で両グループを区別 するが，病人と正常人は厳密な区別はないのではない か。池田「病人と正常者について意見はもつてるがのべ ない。Tグループに集まる人は病気治療を目的として入 つて来ないが，治療集団はそれが目的である。」

2. 井原はTグループが役立た刚といらが，どらいう Tグループをやつたのか。やり方が悪いのではないか。
井原「一般に現場では役立たぬと感じている事をいつた 迄で, やり方を変えればいいかもしれない。」

3. 井原が訓練をいう場合, 監理者自身が変らねばな らないが，どうか。井原「監理者は変らねばならない。」

4. 堀江は我と汝の人間関係を主張するのは賛成だ が, いろいろな宗派があるのはどうか。堀江「エキメニ ズムの運動といつて, 各教派の相違を超越しょうとして いるが，このTグループその一つの方向に 合致してい る。」

5. 関は here and now に徹せよといらが, 過去の 原因を見なくてよいか。関「here and now といらの は, 過去は現在の心境の中に摄取されるといら事で, 過 去をして規定させるのは現在だ，といら意味である。ち ようど，禅宗の随所に主となると同様な趣旨だ。

6. 関の here and now と現場との関係はどらなる か。関「here and now だけでは不完全だから，現場へ の応用, すなわち there and then の修練をはじめは 重んじたが，Tグループの目的が Group の成長発達と いらことよりも，個人の発達におかれるようになるにつ れて，現場への応用の修練をするより， here and now の修練をしたほらがよいと考えられている。

7. 池田は発表のはじめに psychotherapy in group という意味で, 個人の治療が目的である精神分析学。グ ループが個人以上の神経症的現象を呈する場合のグルー プ・エゴ，グループ・アナリシスをする Maudsley, Eonlkes らの中間的立場。グループ・ダイナミックス の影響があつて、はじめにグループがあり, グループの 中ではじめて個人が本性をあらわすとする Bien の立場 をのべた。しかし, 討議の過程で, この.3つの区別はあ つても，究極はどれも個人治療が目的であると述べた。

8. さらに池田は Tグループが個人中心になるにつれ て, トレーナーの責任が重大である点を強調した。これ はノン・ディレにしても，その結果に対する責任がグル ープにあるのでなく，あくまでトレーナーにあるという 主張で, 注目をひいた。

9. アメリカの $\mathrm{T}$ グループに 今夏参加した人から， 「Tグループは本当の自己を表明して交わることが特色 である」という意見がよせられた。

(6) グループは元来, 理屈ではないので，その体験を もたないでの論議がじつにもどかしい感じであつた。し かし, 単に心理学者だけでなく, 精神医学者, 産業界の 訓練担当者, 宗教家など異質的なメンバーをあつめての シンポジウムは効果があつたと思う。 


\section{T-Group と治療集団}

池 田 数 好

T-Group (T-G) のもつ, いろいろの特性を, 治燎 集団（Th-G）のもつそれと比較しながら，考察してみ るといらのが，演者に与えられた課題である。この場 合，T-G あるいは Th-G といつても，それを実施す る人の立場も，したがつてまた，その技法も，かならず しも同一でない。比較のためには，いつたい，どのよう な理論，目標をもつ T-G が，どのような基礎理論でく み立てられた Th-G と比較されるのであるかが，まず 問われなくてはならないであろう。しかし，このこと は，以下の考察のなかで，その幾分かを明らかにするこ とにして，ここでは，Th-G として，精神分析学的に 構成された (Psychoanalytically oriented) 神経症の治 療集団を頭において，論をすすめることにしたい。

すると, 注意すべき第一の点は, 両集団を構成するメ ンバーの相異である。すなわち, 前者は, いわゆる正常 者の集団である。ここでは, 正常者と神経症者との本質 的なちがいがあるのかないのか，あるとすれば，それは なにであるか, といつた問題にはふれない。とにかく治 療集団のメンバーが，いずれも，それぞれ，なんらかの 症状に悩み，治療意照をむつて構成されて抢り，その意 味では，同質の集団であるのにたいし，T-G では，目 標が必ずしも明確でない。集団参加の Motivation とし ては，せいぜい，〈何等かの学習をよる〉といつたとこ ろが, 共通項としてとりだせる程度かもしれない。それ さえ、メンバーによつて相異していることもあり得る。

このことから，第二の点として，両集団に利ける Leader-Member Relationship に大きな差異がでてく る。たとえば前者では, Leader (この場合は Therapist) は集団メンバー（patients）によつて選択され，治療と いらおなじ期待をおわされた，集団のなかの特異な，異 質な一人物である。後者では, Leader（この場合 Trainer）は,メンバーの意志とはまつたく無関係に，ただ 自らがそうだと名のる型でそこに存在している。それ は，せいぜい， Expert-Member Relationship といつ たものから，他のメンバーと同質のものに近い影きょう を, 各メンバーに与えているにすぎない。

以上のような, 集団参加の Motivation の同質性・異 質性のちがいと，Leader の異質性・同質性のちがいは， 両集団の Group dynamics に著しいちがいがいをうむ はずである。

ところが，このよらな相違点をもちながら，両集団 は、、きわめて類似した型で操作されるのである。すなわ
ち，両集団で用いられる技法は，一言でい党ば，非指示 的なfree floating discussion の方法である。

治鎳集団にあつては，このような技法は，上くしられ ているよらに，神経症的に武装したその防衛体制を，い わば, 安心させ, くつろがせ, 油断させることで, つき くずしてゆく結果となる。それによつて，内面のかつと らは，集団の中で，自他にたいしてあらわになり，その 経験をと打して，バースナリテイの再構成が進涉する。 すなわち治療がすすんでゆく。

ところが，T-G に执いては，同一の操作をうけとめ るものが，いわゆる正常者の集団であり，乙かもその集 団は，前にのべたように，異質的な無構造の 集団であ る。がんらい，正常な人間集団は，集団を形成するや否 や, 不可抗的に, 集団の目標を設定する自然の傾向をる つ。すなわち, Work Group への構造化をおこすもの である。ところが，T-G に拈いては，集団の果すべき 目標が与兄られない。そこでは，心浮ぶ何事を話題に してかまわないし，行動についてのなんらの制限もな い。メンバーは，交字ど扔り自由である。Work Group への自然的傾向をもつた, 集団の各メンバーにとつて, このような状況は, 実は, まことに, 奇妙な逆説的な状 態を形成することになる。メンバーにとつて，T-G は， 目的がないといら制限，なとを話してもかまわないとい ら禁止，すべて自由であるといら不自由さ，を提供する ことになる。治療集団のメンバーにとつては，解放であ つた条件が, ここでは禁止, 制限となり, 構造化への阻 止となる。全セッションを通じて，くりかえし Work Group への動きを試みながら，制限のないといら制限， 自由であるといら不自由さの故に，それは失敗する。各 メンバーのなかに，しだいに不快で苦痛な緊張がたかま り，その緊張の故に，各メンバーの自我の統合はゆりう ごかされ，破れ目をつくり，そこから，日常生活のなか

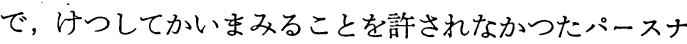
リテイのある内面が集団のなかへ project されてくる。 メンバーは，かつて経験することのなかつた別の自他を そこに発見する。

このよらにして,ひとつのセッション, ひとつの断面 をとつてみると，そこであらわになる集団現象は，両集 団によつて，きわめて近似した Psychodynamics をも つたものとなる。ただ治療集団にあつては，神経症的防 衛が, 非指示的, 受容的態度, 解釈をと抏して, エスの 解放, 自我の自壤作用を抏こしながらこの状態に近づい てくるし，T-G にあつては，自我の極度の情緒的緊張 をとおして, 自我, 上位自我の動摇を招来しながらこの 
状態を現出する。

治療集団との比較で明らかになる $\mathrm{T}-\mathrm{G}$ の以上のよう な特徵は， T-G の実施にたいするつぎのような，幾つ かの問題点を反省させることになる。

1） T-G の目的をいつたいどこにおくかといら出発 点からの反省である。歴史的には，たしかに T-G は, 集団内に打ける相互作用の 理解, 集団現象の学習と体 験といつたものを，その主な目的としていた。く社会 的感受性の訓練〉とよばれるものもそれである。しか し, 集団内のもろもろの心理現象, 集団発達の諸相を, たんに学習し体験する意味であれば，T-G が，もつと も効果的な方法であるのかどらか。トレーナーにせよ， 各メンバーにせよ，あれほどの労力と時間を費すならば， 他により有効な学習，訓練の方法がみいだされると打も えるのである。しかも，T-G の内部に生起する条件は， 前述のように, 治療集団に近似したものをそなえてい る。

2）以上のことから，歴史的にも，T-Gはしだいに， 学習・訓練集団から, 各メンバーの, なんらかの意味で のパースナリテイ変革を目指す，一種の治療集団的の性 格へと，その目的を発展させてきているようである。 また，T-G の実施に伴つて，この意味での効果が 期待 できないとすると，実際的にも，T-G の効果は，はなは だ危いものとなる。これに参加し，幾つかの経験・学習 をつんだがために，かえつて集団内での行動，適度が低 下してくるという現象も予測されるわけである。実効を 強調する企業方面で, $\mathrm{T}-\mathrm{G}$ への参加者のなかから, 現 場にかえつてのちに，いわゆるく骨ぬきの>指導者がう まれたとの非難がうまれかねない批判がでていることも これを示しているのである。単なる感受性のたかまり は,がんらい,このような危険を伴つている。

ここで，T-G は，いわば, 正常者にたいする治療集 団の役割を果すものとならなくてはならない。すくなく とも，学習・訓練と同時にこの目標が実現されなくては ならない。学習・治療といつた目的の割合がぞのような ものとなるかは，抢そらく，与えられた時間数，トレー ナーの力量, 全体としてのメンバーの組合せなどの要因 によつて決定されることになるであろう。

3）このことから，さらに重要な一つの問題がでてく る。それは，トレーナーの集団にたいする責任の問題で ある。T-G の実施が，単に一つの学習の型態にとどま るならば, トレーナの責任は, 学習効果に奇与し得たか 否かの，比較的かるいるのにとどまるであろう。しかし ながら、これが治療的なものを目標とするか，あるいは
意図的にそれをなさないとしても，現象として同一のも のを集団内に生起させてくるとなると,トレーナーの責 任はまことに重大になることを考えなくてはならない。 メンバーの情緒的緊張をたかめ，いわばパースナリテイ の統合をゆさぶつて，その再統合をはかるといら操作 は, 抢そらく心理療法の終末操作とおなじ手続を必要と するであろう。しかも，それが T-G セッションの終結 にむすびつけて実現されなくてはならない。そのことが なされないならば，学習面はとにかくとして，情緒面に 执いて,メンバーのパースナリテイは，ある種の人為的 な傷痕をのこしたままに T-G は終了するという好まし くない結果となる。極端な場合には, ある種の心理障害 を出現する結果ともなりかねない。

演者自身は，T-G の実施にたいし，むしろポジテイ ブな考えをるつものであるが, 以上の意味で， T-G が あまりに不用意に，流行的に実施されることには賛成し かねるものであり，この傾向が；実はわが国にないとは いえない気がするのである。

\section{キリスト教会の立場に於いて}

堀 江光 児

工学的グループ・ダイナミックスは, 人間関係の変容 の操作を意図しているし，キリスト教会も同様に人間関 係の改善を願つている。両者が同し人間関係の改善を意 図しているかぎり，両者は同じはたらきではないか。も しそらなら科学的なグループ・ダイナミックスのはたら きは宗教活動に代ることも可能ではないか。

、産業訓練に於いても，心理治療の場面に於いても，人 間関係の改善から人格構造の再編成のために，それぞれ の研修会に於いてTグループがもたれているとしたら， それらのTグループと教会の研修会のTグループと質的 な相違があるのか。それらをミックスしたTグループが 可能なのかどうか。こうした疑問は当然おこるだろう し，教会の立場からその疑問に答えなければならない。 教会に於いて理解されている人間関係は, 教会の外の 一般的人間関係とは違つている筈なのだが，その区別が 教会内部の人々にどの程度に明確に自覚ざれているだる らか。教会の生命は「交り」(コイノニア) であると云 われているが，現代の教会は，この教会独自の「交り」 の意味を, 現実にその場に於けるキリストあつての人間 関係としてどの程度とらえているだろらか。

教会に属する人々が敬虔な態度で礼拝をささげてはい るものの, 若しそれが単なる個人主義的な孤独な個人が 集つて，拈のおの個別的な気持から礼拝をしているとし 
たら，そこでどのような深い「交り」の意味についての 説明がくり返えされていても生きた「交り」は存在して いるとは云えない。

これは教会に於いてだけ云われることでなく，一般現 代社会に於いても同様に人間関係と云うコトバは広く使 われているが，現実にはどのような生きた人間関係が成 立しているのだろらか。人が人と対面したとき相手の人 をどのように受け取り合つているのだろらか。動物学的 な人間としてか，生産に役立たせようとしての機械的な 人間としてか，とに角人間を人格としてより「モノ」と して受け取つている場合の人間関係を云つている場合が 多いのではないだろらか。!この点について哲学者 $\mathrm{M}$. ブーバーは“Ich und Du” に於いて次のように述べて いる。一般に人間関係と云われるものを，「人と人」と の関係と，「人とモノ」との関係の二つに分析して，前 者は「我と汝」の関係であり，後者は「我とソレ」との 関係であると云つている。

人間関係と云つても，相手を人格として受け容れてい るのか，人格として受け容れることを拒否して「モノ」 に格下げして受け取つているのかによつてその関係の仕 方は違つている。生産工場の経営者がそこで働く人に対 して，商人が客に対して，教師が生徒に対してどんな人 間理解のもとに相手と接しているのであろらか。

今日，一般社会の傾向として従来もつてきた人間理解 について反省し始めてきた。産業界に於いてさえも人間 性を無視しては生産性を高めることができないことに気 付いてき，そのために研究と努力がなされている。われ われキリスト教会に於いても，神の前に於ける兄弟とし ての「交り」を回復するために人間関係を科学的に研究 しなければならなくなつた。しかし教会に於ける人間関 係の理解は一般世俗に於ける理解と質的に違つている。 即ち人間が偶然的に人間関係をつくるのではなくて, 親 によつて先づ兄弟関係がつくられるように，人間関係は 神によつてつくられた必然的な，宿命的なものであると 云らことが根本的な理解である。

神が天地の創造に続いてアダムと云う男を創造した神 は，「人がひとり怙るのはよろしくない。彼のためにふ さわしい助け手を造ろら」と,アダムのあばら骨をとつ て彼のために女イブをつくつた。ここに初めて人間関係 と云うものが神によつて成立させられたのだ。だから人 間関係と云うものは, 教会の理解では, 神によつて成立 され，神によつて人々は関係づけられ，その関係のなか に神が聖霊として介在して，その関係を深くされるの だ。したがつて神の合せたものを人が離してはならない
と云うことになる。

だから教会に於ける「交り」は, 聖需によつて導かれ ることによつて神の求める「交り」の状態に改善され得 るのであるから，人間関係のなかに聖霊が充分はたらく ときには，そこに横たわつている障害が除去され改善さ れるのである。

教会に於ける人間関係が一般的なそれと異る第二の点 は, 神に常にその人間関係の状態が見られていると云う ことである。旧約聖書の創世記に記されているカインと アベルの兄弟関係のように, 神からその兄弟相互の関係 が愛の関係であるかどらかが見守られていると同時に， 個人の好悪感情から勝手に人間関係を破衰导ることは神 から許されていない。弟アベルを殺した兄カインに対し て「カインよ，弟アベルはどこにいるか」との神の問に 対して，カインは「知りません。私が弟の番人でしょう か」と答えた。カインが弟アベルを殺すに至つたのは， 弟に対する娭妬からであつたとしても，弟との愛の関係 を持続するこことを拒否しようとしたことによつて，カイ ンはその非を悟つて神の許しを得るまで神と人との間の 「交り」に復帰することが許されなくなつた。

このことは，人が相手を人として交ることを拒否すれ ば，彼自身む神と人から人として交ることを拒絶され， したがつて彼自身は人としての成長は望めなくなつてし まうことを意味している。即ち人が人との愛による受容 的な相互の「交り」のなかに実存的に存在するとさにはじ めて人としての成長を可能にするものである。教会が世 俗一般と同じょうにく人間関係」と云うコトバを用いてい るが，そのコトバの内容は以上のことから相違している ことが明確にされると思う。即ちその人間関係は神によ つて造られた関係であり，神から絶えず見られている関 係であり，神を除外しての人間関係は存在し得ないもの だと考えられている。だから只単に人と人との人間関係 が改善されることだけで解決したと考えることができな い。そこには同時にその関係を造つた神，その関係を見 守つている神との関係を同時的に正常に戻すことを考兄 なければ真の解決とはならない。何故ならアダムーイブ 関係は人の意志によつてつくられたのでなく，それ以前 に神の意志によつて成立させられたものであり，したが つて我一汝の関係も，その関係が偶然的に成立したそれ 以前に神の意志によつて成立させられたものであるか ら，人と人との関係の改善は人に対する当為であると同 時に，神に対する当為として考えているからである。

人間関係の改善が神に対する当為としても考えられる ところから，その改善を怠り，或はその関係を改德した 
りすることは，その意志決定をその主体が罪として自覚 せざるを得なくなる。神を愛していると云いながら兄弟 を憎む者は神に対して偽り者であると聖書は教えている が，その意味は前に述べたところからすれば，相手との 現在の関係がどのような状況にあろうと神の要求してい る兄弟関係に復帰するように努力しなければならないと 云うことである。たと光現在に於いて相手とは仇敵の関 係にあろうとも，仇敵関係なるが故に相手との関係を破 菓することは神の前に許されない。そればかりかイエス は「なんじの敵を愛しなさい」「なんじの仇のために祈 りなさい」と更に積極的な受容態度を求めている。

このよらな仇敵をも積極的に受容しなければならない 高度の人間関係の要求は結局十字架を負わ水ばならない きびしい道として受けとらなければならない。

キリスト教会に於いて行われる研修会のTグループの 中で起る各メンバーの苦悩は，他の世俗的一般の T グル ープに於いて経験される苦悩とは以上のことからして当 然質的に違つたものであるべきであるら。即ちそれは一 般的な心理的不適応な人格構造と違つて, 神と兄弟との 「交り」への不適応な自己の態度や行動が神に対する罪 責として自覚され，その罪責感に苦恼するのである。こ の苦悩は普通一般の心理的治療やカンセリングで癒すこ

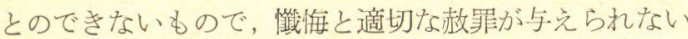

かぎり癒されない精神的な死に至ることを意味する性質 のものである。

私は過去 8 回にわたつて経験した研修会に於汀 T グ ループのメンパーの中で強度の不適応状態に陥つた人を みてきたが，クリスチヤンの場合とノンクリスチヤンの 場合ではその症状に於いても, その治癒の過程に於いて も質的に相違しているのは, クリスチャンの人間関係の 理解の仕方が，ノンクリスチヤンと相違しているからだ と云うことが抢分りいただけると思う。

最後に一。イエスは「ふたりまたは三人がわたしの名 によつて集つているところにはわたしもその中にい る」と云つているが，そのよらなキリスト教の生命的な 真の「交り」がクリスチヤンに体験的に理解されなけれ ばならないのであるが，それにはどらすればよいか。

「小さい者の一人をつまづかせる者は，大きなひきうす を首にかけられて海の深みに沈められる方がその人の益 になる」とのイエスのコトバは，賀しい小さな相手との 関係のきびしさを示している。このよらなきびしい関係 によく堪えていけるためには，正しい人間関係の改善の 方法を自ら発見し，矢の方法に於いて遂行していける自

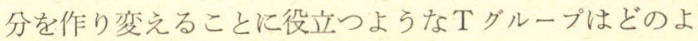
らにすべきであるうかは，な抢今後に残された重要な課 題である。

\section{シンポジアム 3}

\section{教育における心理学の役割}

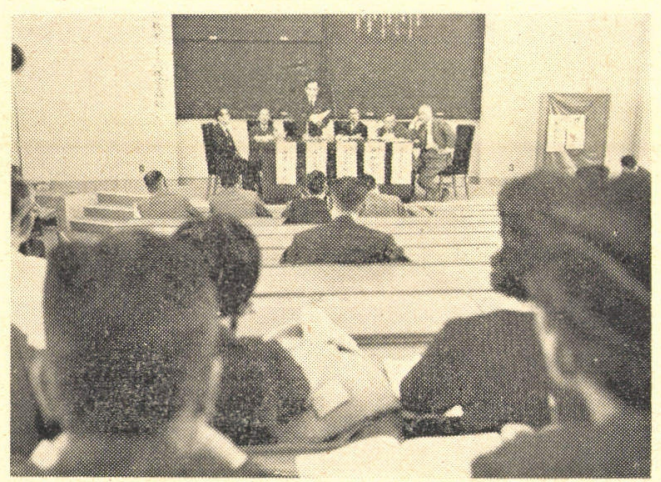

10月 5 日（月） 9:00〜12:00 大講堂において開催 されたシンポジアムでは，

司会

教育原理と心理学
牛島 義友 (九 州大学) 波多野完治（扣茶の水大学）
教育挍術と心理学 中野 佐三 (東京教育大学) 生徒指導と心理学沢田慶輔（東 京大学） 幻览教育・家庭教育と心理学

山下 俊郎 (東京都立大学) 社会教育・青少年問題之心理学 山根悪 (埼玉大学) による発表と討論が行なわれた。

\section{教育原理と心理学}

波多野 完 治

\section{(1) 主人となつた奴婚}

心理学と教育原理との関連を考えるとき, 決定的なポ イントは「教育目的」の問題である。さかしは, 教育学や 教育哲学が教育の目的を設定し, 教育心理学がその目的 を達成する方法を研究する，といら風に考えられた。こ 